\title{
Three new species and synonymy in Nealcidion Monné (Coleoptera, Cerambycidae, Lamiinae)
}

\author{
Miguel A. Monné1 \& Marcela L. Monné ${ }^{1}$ \\ ${ }^{1}$ Museu Nacional, Universidade Federal do Rio de Janeiro, Quinta da Boa Vista, São Cristóvão, 20940-040 Rio de Janeiro-RJ, Brazil. Fellowship \\ CNPq. monne@uol.com.br
}

\begin{abstract}
Three new species and synonymy in Nealcidion Monné (Coleoptera, Cerambycidae, Lamiinae). Three new species of Nealcidion Monné are described: N. antennatum Monné \& Monné sp. nov. from Panamá and N. albolineatum Monné \& Monné sp. nov. and N. elegans Monné \& Monné sp. nov., from Venezuela. Alcidion deletum Bates, 1880 is considered a synonym of Nealcidion strigilis (Erichson, 1847) comb. nov. The four species are illustrated.
\end{abstract}

KEYWORDS. Acanthocinini; Neotropical region; new combination; synonymy; taxonomy.

RESUMO. Três novas espécies e sinonímias em Nealcidion Monné (Coleoptera, Cerambycidae, Lamiinae). Três novas espécies de Nealcidion Monné são descritas: N. antennatum Monné \& Monné sp. nov. do Panamá e N. albolineatum Monné \& Monné sp. nov. e N. elegans Monné \& Monné sp. nov., da Venezuela. Alcidion deletum Bates, 1880 é considerada sinônimo de Nealcidion strigilis (Erichson, 1847) comb. nov. As quatro espécies são ilustradas.

PALAVRAS-CHAVE. Acanthocinini; região Neotropical; nova combinação; sinonímia; taxonomia.

Monné (1977) proposed the generic name Nealcidion to replace Alcidion Thomson, 1860 (not Sturm 1843), because Sturm proposed the name Alcidion to accommodate Acanthocinus humeralis Perty, 1832, type species of Probatius White, 1855.

Nealcidion contains 54 species (Monné 2005), and it is largely distributed in the Neotropical region. Bates (1863: 105), proposed two groups of species, the first group is distinguished by having a raised dorsal carina along the whole length of the elytra, from the centro-basal crista to the external apical angle and the second by the absence of dorsal carina and by the centro-basal crista usually very prominent. Monné (1998) published a key for all the 16 species of Nealcidion belonging to the first group.

This paper has the objective to contribute to the knowledge of the genus increasing the number of known species of Nealcidion to 57.

Abbreviations cited in the text: ACMT, American Coleoptera Museum, San Antonio, Texas, USA; MNHN, Muséum National d'Histoire Naturelle, Paris, France; MNRJ, Museu Nacional, Universidade Federal do Rio de Janeiro, Rio de Janeiro, Rio de Janeiro, Brazil; USMN, National Museum of Natural History, Washington, D.C., USA; ZMHB, Museum fur Naturkunde der Humboldt-Universität, Berlin, Germany.

\section{Nealcidion strigilis (Erichson, 1847) comb. nov.} (Fig. 1)

Liopus strigilis Erichson, 1847: 147. Leiopus strigilis; Monné, 2005: 55 (cat.).

Alcidion deletum Bates, 1880: 274, syn. nov.

Nealcidion deletum; Monné 1977: 700; Wappes et al. 2006: 36 (distr.); Morvan \& Morati 2006: 31 (distr.).
The comparison between the holotypes of Liopus strigilis Erichson, 1847 (ZMHB), described from Peru, and Alcidion deletum Bates, 1880 (MNHN), described from French Guiana, and the examination of 15 specimens (MNRJ) allowed us to propose the new synonymy.

This species is recorded from French Guiana, Brazil (Amazonas, Pará, Rondônia), Peru and Bolivia. Now we extend the range of distribution to Colombia and Venezuela.

Material examined. COLOMBIA, Norte de Santander: $3 \mathrm{~km} \mathrm{~N}$ Chinacota, 1 male, 12.V.1974, H. \& A. Howden col. VENEZUELA, Carabobo: Rio Borburata $(250 \mathrm{~m}), 1$ male, 18-23.I.1972, F. Fernandez Y. \& A. D. Ascoli col. PERU, Apurimac: Valle cerca de Abancay, 1 male, 2.VII.1948, C. S. Carbonell col.; Huanuco: Tingo Maria, 1 male, 19.VII.1948, C. S. Carbonell col.; Junin: Satipo, 1 male, VI.1941, without collector; 3 females, IX.1942, without collector; Madre de Dios: Loromayo, 1 female, 4-10.IX.1962, L. Peña col.. BRAZIL, Amazonas: Atalaia do Norte, 1 female, XII.1977, B. Silva col.; Benjamin Constant, 1 male, V.1942, A. Parko col.; Santo Antonio do Iça, 1 female, 20-30.VIII.1948, C. S. Carbonell col.; Tabatinga, 1 female, X.1977; B. Silva col.; Pará: Utinga, 1 male, 1.V.1961, J \& B. Bechyné col.; Rondônia: Ouro Preto do Oeste, 1 female, XI.1982, O. Roppa, J. Becker \& B. Silva col. All specimens are deposited in MNRJ.

\section{Nealcidion antennatum sp. nov.} (Fig. 2)

Etymology. Latin, antennatum, means elongate antennae.

Male. Integument blackish. Body with predominance of brownish pubescence. The brownish-yellow pubescence covers an irregular longitudinal spot each side of the middle of the pronotum and a transverse stripe in the middle of the elytra. The black pubescence covers an oblique patch each side of the middle of the pronotum, the sides of the scutellum and sparse rounded spots in the whole surface of the elytra, 
more dense in the apical half. The grayish-white pubescence covers a narrow ring in the base of the segments 3-9 of the antennae, a transverse stripe in the middle of the femorae and tibiae, the first three tarsomeres and $3 / 4$ of the base of the proximal. Antennae and legs with sparse grayish pubescence.

Antennae more than twice the lenght of the body, exceeding elytral apices at middle of segment 5. Segments 1-4 with black pubescence in the latero-ventral face. Prothorax with lateral tubercles obtuse; pronotum with rounded tubercle each side of the middle, covered with black pubescence; with a row of coarse punctures on posterior margin and a few ones in the anterior margin. Prosternum and mesosternum with intercoxal processes broad, about $3 / 4$ as wide as one coxa. Center of the metasternum densely covered with silver short pubescence. Elytra with elevated centro-basal crista, densely covered with black hairs; coarsely and densely punctate on basal third, each puncture provided with a black and bright granule in the anterior margin; apical $2 / 3$ densely and deeply punctate, without granules. Elytral apices obliquely truncated. Fifth urosternite and urotergite triangulary notched in the apical margin.

Female. Antennae exceeding elytral apices at apex of segment 6. Metasternum without silver pubescence. Fifth urosternite with apical margin truncated; urotergite acutely pointed; ovipositor slightly projected beyond elytral apices.

Measurements in $\mathrm{mm}$, male paratype - male holotype/female paratype. Total length, 9.5-12.9/11.0; prothorax length, 1.52.0/1.8; prothorax width, 2.2-3.3/3.0; elytral length, 7.5-9.6/ 9.5; humeral width, 4.2-5.4/4.6.

Type material. Male holotype, PANAMA, Chiriquí: $21 \mathrm{~km} \mathrm{NW}$ Volcán, 20.V.1996, Wappes, Huether \& Morris col. (USNM). Paratypes, same data as holotype, 1 male (MNRJ). Chiriquí: $6 \mathrm{~km} \mathrm{~N}$ Fortuna, 1 male, 16-17.IV.1993, J. E. Wappes col. (ACMT). Hartmanns Finca, 1 female, 4-7.VII.1997, Wappes \& Morris col. (ACMT).

Comments. Nealcidion antennatum sp. nov. belongs to the second group of species defined by Bates (Bates 1863), with the elytra without raised dorsal carina and the centrobasal crista usually very prominent. Six species of this group are distributed in Mexico and Central America: Nealcidion brachiale (Bates, 1872), N. cuspidatum Monné, 1998, N. eulophum (Bates, 1881), N. furciferum (Bates, 1881), N. privatum (Pascoe, 1866) and N. scutellatum (Bates, 1881). N. antennatum sp. nov. differs from them by the elytra with centrobasal crista provided of a long black brush of hairs in the top and by the elytra with numerous rounded black spots in the whole surface, more dense in the apical half.

\section{Nealcidion albolineatum sp. nov.}

(Fig. 3)

Etymology. Latin, albus means white + lineatum, reference to the fasciae of the elytra.

Male. Integument dark brown. Body with predominance of dark brown pubescence. White pubescence in a narrow curved longitudinal fascia each side of the middle of the pronotum; on elytra, an intricate design, basically, a sutural fascia from behind the scutellum to apex, narrowed and trifurcated in longitudinal curved fasciae on the basal half, from suture to base and a fascia from humeri joined with the external anterior curved fascia. White sutural fascia interrupted in the middle by brown rounded circular spots, and by a longitudinal spot before the apex. Apical 3/4 of the elytra with brown rounded spots, connected by a narrow yellowish longitudinal fascia.

Antennae exceeding elytral apices at apex of segment 8; segment 11 appendiculate in the apex; segments 1-7 with short, sparse setae in the ventral face. Prothorax with obtuse lateral median tubercle; pronotum with three obtuse calli disposed in a triangle, one median and two near anterior margin; with a row of coarse punctures on posterior margin. Prosternum and mesosternum with intercoxal process broad, about $3 / 4$ as wide as one coxa. Elytra with a glabrous and low centro-basal crista, with a dorsal longitudinal carina from base to apex; coarsely and densely punctate on basal third, the apical $2 / 3$ sparsely and deeply punctate. Elytral apices obliquely truncated; external angle produced in a stout spine. Fifth urosternite and urotergite semi circularly notched in the apical margin.

Measurements in mm, male holotype. Total length, 11.5; prothorax length, 2.0; prothorax width, 3.2; elytral length, 8.6; humeral width, 4.4 .

Type material. Male holotype, VENEZUELA, Lara: Parque Nacional Yacambú (9,5km E Sanaro, 1650m), 19.VI.1999, Rattcliffe, Jameson, Smith \& Villatoro col. (USNM).

Comments. Nealcidion albolineatum sp. nov. belongs to Bates's first group (Bates 1863), characterized by having a raised dorsal carina along the whole length of the elytra. This species is distinguished from others of the group by the distinctive elytral pattern, with an intricate design of white fasciae in the pronotum and elytra (Fig. 3).

\section{Nealcidion elegans sp. nov.}

(Fig. 4)

Etymology. Latin, elegans means fine, select.

Female. Integument dark brown; antennae, femora, tibiae (partially) and ventral face, brownish-yellow. Body with predominance of brownish-yellow pubescence. The black pubescence covers in the pronotum two circular spots, one each side of the middle; a circular spot on the posterior margin of the side of prothorax and a post median undulated fascia in the elytra; the whole surface of the elytra with minute black spots, more dense in the basal half; in the antennae the apex of segments 3-11; base and apex of the tibiae, $3 / 4$ of the basal surface of the first and last segment of the tarsi and the whole surface of the two intermediaries. Apex of the scutellum yellow. Antennae exceeding elytral apices at apex of segment 6; segments 1-4 with short sparse setae in the ventral face. Prothorax with obtuse lateral median tubercle; pronotum with a single row of coarse punctures on posterior margin. Prosternum and mesosternum with intercoxal process broad, about $3 / 4$ as wide as one coxa. Elytra with longitudinal centro- 

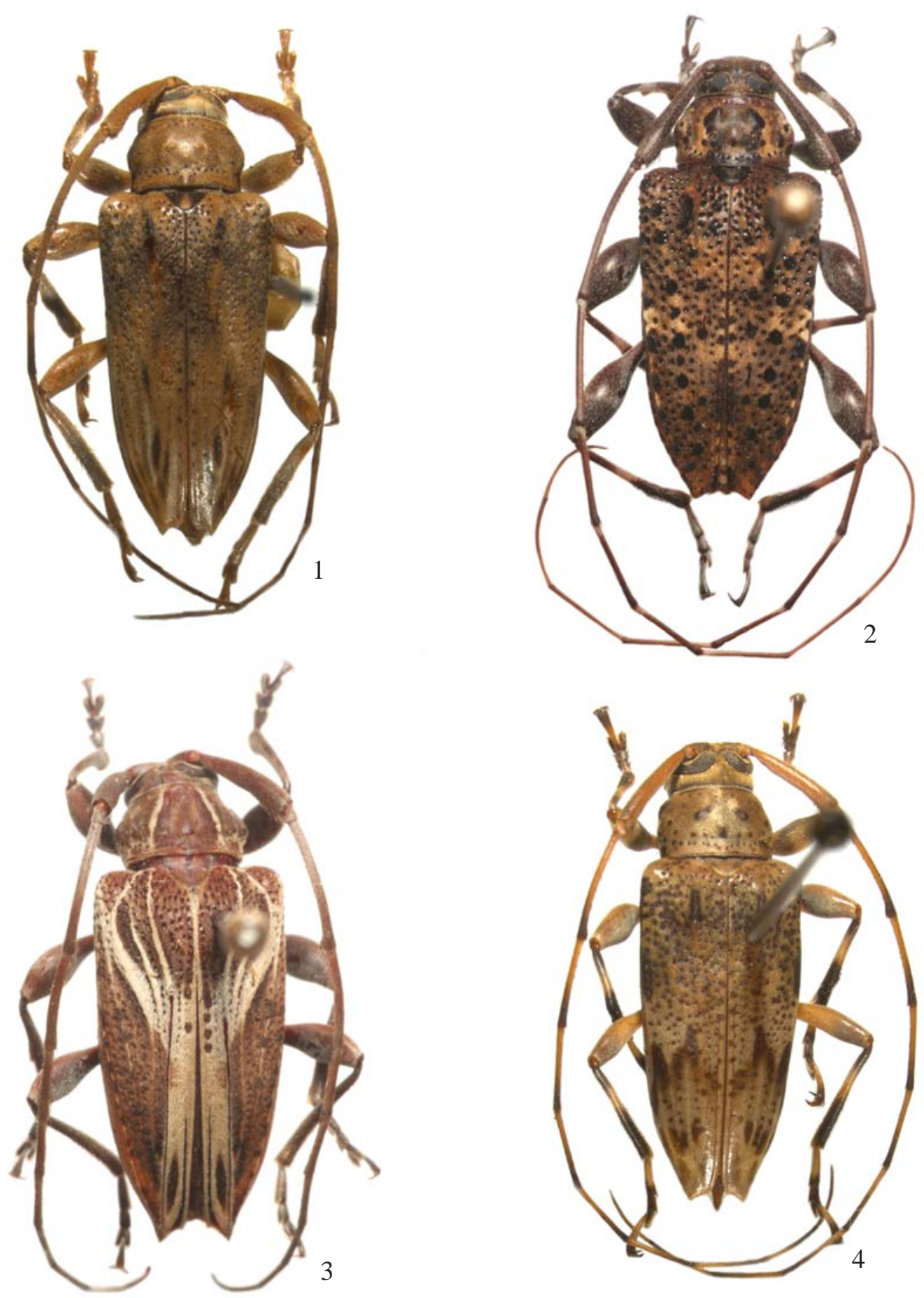

Figs. 1-4. 1, Nealcidion strigilis comb. nov., female, $9.0 \mathrm{~mm} ; 2, N$. antennatum sp. nov., male holotype, 12.9 mm; 3, N. albolineatum sp. nov., male holotype, $11.5 \mathrm{~mm}$; 4, N. elegans sp. nov., female holotype, $9,7 \mathrm{~mm}$.

basal crista, with a few short black setae on the top; coarsely and densely punctate on $2 / 3$ basal, the apical third sparsely punctate. Elytral apices semi circularly emarginated, angles not projected. Fifth urosternite with apical margin rounded; urotergite acutely pointed; ovipositor slightly projected beyond elytral apices.
Measurements in mm, female holotype. Total length, 9.7; prothorax length, 1.6; prothorax width, 2.5; elytral length, 7.2; humeral width, 3.5 .

Type material. Female holotype, VENEZUELA, Bolívar: El Dorado-Santa Elena, km 140 (1300 m), 27.X.1972, J. \& B. Bechyné col. (MNRJ). 
Comments. N. elegans sp. nov. belongs to the second group of Bates (Bates 1863) defined by the absence of dorsal longitudinal carina in the elytron and distributed in Venezuela. The species are: $N$. deletum (Bates, 1880), N. griseum (Aurivillius, 1900), N. melasmum Monné \& Delfino, 1986, N.meridanum Monné \& Delfino, 1986, N. privatum (Pascoe, 1866), N. socium (Gahan, 1895), N. spinosum Monné \& Delfino, 1986, N. triangulare (Bates, 1863) and N. trivittatum (Bates, 1863). All the mentioned species (except $N$. trivittatum) have tubercles or calli more or less elevated in the pronotum, absent in N. elegans. Nealcidion trivittatum differs by the presence of a large triangular black spot in the middle of the pronotum and by the white fasciae in the elytra, in $N$. elegans, the pronotum has two circular spots each side of the middle and there is no white fasciae in the elytra.

Acknowledgments. We are grateful to CNPq for Grant No. 471726/ 2007-9, to Fundação Carlos Chagas Filho de Amparo à Pesquisa do Estado do Rio de Janeiro (FAPERJ) for Grant No. E-26/171.281/2006, and to James Wappes (ACMT) for sending specimens to identify.

\section{REFERENCES}

Bates, H. W. 1863. Contributions to an insect fauna of the Amazon Valley. Coleoptera: Longicornes. The Annals and Magazine of Natural History 12: 100-109.

Bates, H. W. 1880. New species of Alcidion, a genus of longicorn Coleoptera. The Entomologist's Monthly Magazine 6: 273 274.

Erichson, W. F. 1847. Conspectus insectorum coleopterorum quae in Republica Peruana observata sunt. Archiv für Naturgeschichte 13: $67-185$

Monné, M. A. 1977. Contribuição ao conhecimento dos Acanthocinini. VI (Coleoptera, Cerambycidae, Lamiinae, Acanthocinini). Revista Brasileira de Biologia 37: 693-711.

Monné, M. A. 1998. Notas sobre Acanthocinini neotropicais (Coleoptera, Cerambycidae, Lamiinae): gêneros e espécies novas. Revista Brasileira de Entomologia 41: 289-295.

Monné, M. A. 2005. Catalogue of the Cerambycidae (Coleoptera) of the Neotropical Region. Part II. Subfamily Lamiinae. Zootaxa 1023: $1-759$.

Morvan, O. \& J. Morati. 2006. Contribution a la connaisance des Cerambycidae de la montagne de Kaw, Guyane Française (Coleoptera). Lambillionea 106: 3-63.

Sturm, J. 1843. Catalog der Kaefer-Sammlung von Jacob Sturm. Nurnberg, J. Sturm, 386 p.

Wappes, J. E.; R. F. Morris; E. H. Nearns \& M. C Thomas. 2006. Preliminary list of Bolivian Cerambycidae (Coleoptera). Insecta Mundi 20: 1-45.

Received 06/01/2009; accepted 17/06/2009 